\title{
Pharmacokinetics of nasal powder formulations
}

\author{
Yuji Makino Yoshihisa Nishibe $\cdot$ Hideo Matsugi ${ }^{* 1)}$, \\ Yoshitaka Nishimura • Iwao Katsuyama ${ }^{* 2)}$
}

\section{粉末状製剤の家鬼鼻腔内動態}

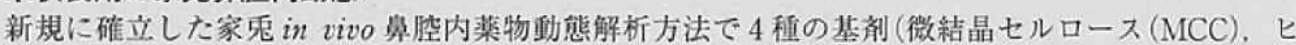

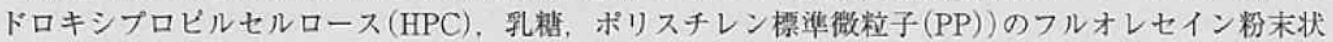
製剂を投与し，フルオレセインの悬腔からの吸収と食道への排出を比較した，HPCについては监光 標職体を用い，またMCCと PPについては画像解析による粒子数測定により，これら基剂 3 種自身 の食道への排出も測定したささらに 4 種製剂からのフルオレセインの放出を in vitro放出試験により 比較した。これらの結果をもとに，血中濃度 $\mathrm{AUC}$ の結果（MCC $>\mathrm{PP}>\mathrm{HPC}>$ 乳糖）に及ほす基剤の効 果を考察した。

すなわち，水不溶性の MCCと PPでは，いずれもフルオレセインの吸収が促進されたが，PPが

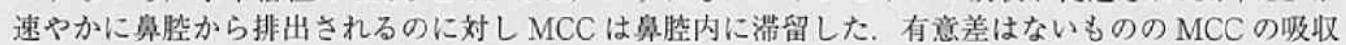
性がより高かったのは，MCC の粘膜付着性により粘膜上にフルオレセインの局所的高濃度が，より 長時間達成されたためと推測した，HPCもMCCと同樣に悬垫内に滞留するが, ゲルが形成される ためフルオレセインの拡散が幄く吸収も排出も少ないと推定される. 一方，乳橧では速やかに溶解す るためフルオレセインの局所的高濃度サイトが生成せず，速やかに拡散して食道へ排出されたと推定 された.

Powder formulations of fluorescein were prepared with carriers, including microcrystalline cellulose (MCC), hydroxypropylcellulose (HPC), and lactose or polystyrene particles (PP), and administered to rabbits intranasally. The order of fluorescein absorption in terms of the AUC was $\mathrm{MCC}>\mathrm{PP}>\mathrm{HPC}>$ lactose. To clarify the differences between the carriers, absorption and elimination of fluorescein from the nasal cavity were simultaneously determined using a newly developed in vivo method. Elimination of carriers was also determined by the method. To quantify insoluble MCC and PP, a new image-analysis method was developed. These results, with in vitro fluorescein release studies, suggest that the schematic role of carriers in nasal delivery is as follows.

Both MCC and PP are insoluble and showed rapid fluorescein release. PP was eliminated rapidly, while MCC was retained in the cavity. This suggests that bioadhesive MCC probably forms a local environment with a higher fluorescein concentration between the particles and membrane. thus resulting in enhanced absorption. In the HPC formulation, fluorescein or HPC eliminations and fluorescein release were sustained due to its gel-forming property. In the lactose formulation. lactose dissolves rapidly, and there may be no means for fluorescein to stay near the mucous membrane. As a result, fluorescein was eliminated rapidly by mucus flow, thus resulting in poor absorption.

\author{
牧野您治・西部垡久·松木秀夫 ${ }^{* 1}$ ， \\ 西村芳卓・勝山 皦 ${ }^{* 2}$ \\ key words : nasal delivery, nasal absorption, clearance to esophagus, \\ powder formulations, carrier
}

Various dosage forms are available for administering drug formulations into the nasal cavity. Among these, nasal sprays of solutions or

*11 帝人ファーマ(株) 㹈寡技術研究所 Pharmaceutical Products Research Laboratories, Teijin Pharma Limited

*2) (株)イーエムアイ Epoch Medical International Inc. suspensions have been well accepted by patients. However, these often have short-lasting local effects or a low rate of systemic absorption. An alternative form of dosage is powder, which has advantages such as increased stability and a reduced need for preservatives. Powders have 
the potential to prolong the drug residence time in the cavity or enhance drug absorption from the cavity when functional materials are used as drug carriers ${ }^{1 \sim 3)}$. Therefore, powder formulations are promising for nasal drug delivery for local or systemic administrations. However, the effects of the carriers on the pharmacokinetics have not been studied to any great degree.

In this work, the absorption and elimination of a drug or carriers from the nasal cavity were studied using a newly developed animal model ${ }^{4}$. Fluorescein as a model for a poorly soluble drug and carriers including microcrystalline cellulose (MCC), hydroxypropylcellulose (HPC), lactose, and polystyrene particles (PP) were mixed to form powder formulations. These were administered intranasally to rabbits, and fluorescein absorption and elimination from the nasal cavity were studied simultaneously. Elimination of the carriers including MCC, HPC, and PP were also studied using the model, and image analysis was used to quantify MCC and PP. The effects of these carriers on fluorescein pharmacokinetics were discussed with the in vivo data and in vitro fluorescein release studies.

\section{Materials and methods}

\section{Materials}

All chemicals except FITC-HPC were commercial products and were used without further purification. Fluorescein was purchased from Wako Pure Chemical Industries (Osaka, Japan). Microcrystalline cellulose (Avicel $102^{\mathrm{TM}}$ ) was purchased from Asahi Chemicals Ltd (Tokyo). Hydroxypropylcellulose (HPC-H) was obtained from Nihon Soda Ltd (Tokyo). Lactose monohydrate was purchased from Iwaki Ltd (Tokyo). These three powders were sieved, and 100 390 mesh $(38 \sim 150 \mu \mathrm{m})$ fractions were used. Polystyrene particles (fluorescent microspheres: certified mean diameter : $79.6 \pm 1.0 \mu \mathrm{m}$ ) were purchased from Duke Scientific Corporation (Palo Alto, CA).

FITC-HPC was prepared as previously report- $\mathrm{ed}^{5)}$. Briefly, $10 \mathrm{~g}$ of HPC-H and $0.1 \mathrm{~g}$ of FITC (Wako Pure Chemical Industries) were mixed homogeneously and immersed in $25 \mathrm{~mL}$ of toluene. The resultant mixture was stirred at $95^{\circ} \mathrm{C}$ for 2 hours. Solids were filtered and washed with 50 $\mathrm{mL}$ of toluene (heated at $50 \sim 60^{\circ} \mathrm{C}$ ), and then washed a further ten times with $100 \mathrm{~mL}$ of a $1: 1$ mixture of $0.01 \mathrm{M}$ phosphate buffer ( $\mathrm{pH} \mathrm{8.0)}$ and $0.15 \mathrm{M}$ sodium chloride aqueous solution. The solids were dissolved in $2,000 \mathrm{~mL}$ of water and then heated to $50^{\circ} \mathrm{C}$ to isolate precipitate. This solubilization and precipitation was repeated three times, and the resultant precipitate was dried to give a yellow solid $(6.41 \mathrm{~g})$. The pulverized solid was then sieved, and a 100 390 mesh (38 150 $\mu \mathrm{m})$ fraction was used for further studies. All other chemicals were of analytical grade.

\section{Particle size}

Particle sizes of HPC and lactose were determined using a Pharmavision 830 (Malvern, UK) image analyzer : in this analyzer, both particles were homogeneously dispersed on a slide glass.

\section{Preparation of the powder formulation}

One part of fluorescein and 100 parts of each carrier were gently mixed in a mortar with a pestle and transferred to a glass bottle. Then, the bottle was rotated on a pair of ball-mill rollers to mix thoroughly and remove any free fluorescein particles. Twenty milligrams of the resultant formulation was filled in a hydroxypropylmethylcellulose capsule (size \#2, Shionogi Qualicaps Ltd, Osaka, Japan) for animal experiments.

\section{Animal experiments}

The powder formulations were administered to operated rabbits, and sample collections followed by fluorescein analysis were performed as reported in a previous study ${ }^{4}$. In separate experiments, carriers including MCC, FITC-HPC, or PP were administered intranasally to study their elimination from the cavity. Esophageal mucus collection, nasal wash collection, and recovery from the capsule and device were performed as 
previously reported ${ }^{4)}$, except that the nasal cavity was washed by water to recover MCC or PP.

\section{Characterization of FITC-HPC}

A comparison of molecular weights between HPC and FITC-HPC as well as detection of any other fluorescent material contamination was performed by gel-permeation chromatography. This included a Shimadzu system, LC-10A (Shimadzu, Kyoto, Japan), with an RI detector (RID$8 \mathrm{~A}$ ) or a fluorescene detector (excitation $493 \mathrm{~nm}$, emission $520 \mathrm{~nm}, \mathrm{RF}-10 \mathrm{AXL}$ ), and separation was accomplished using a TSKgel G6000PWXL, $7.8 \times$ $300 \mathrm{~mm}$ column (Toso Ltd, Tokyo) maintained at $30^{\circ} \mathrm{C}$. The mobile phase consisted of $1: 1$ mixture of $0.01 \mathrm{M}$ phosphate buffer $(\mathrm{pH} 8.0$ ) and $0.15 \mathrm{M}$ sodium chloride aqueous solution. The flow rate was $1.0 \mathrm{~mL} / \mathrm{min}$.

The viscosities of the FITC-HPC aqueous solution at different concentrations were determined using a rotation-viscosity meter (Haake RS60, Germany). Measurements were performed at different shear rates, and viscosity-concentration relationships were plotted at each shear rate.

Glucose unit contents of the precipitate were determined using the anthrone-sulfuric acid method, and the FITC substitution degree was determined by comparison of fluorescence intensity (excitation $493 \mathrm{~nm}$, emission $520 \mathrm{~nm}$ ) to that of FITC-dextran (Sigma, MW 464K, 0.016 moL FITC/1 moL glucose).

\section{Quantitative analysis of the carriers}

The insoluble MCC or PP was quantified by particle count determination with the image analyzer, while FITC-HPC was determined by a fluorescence spectrophotometer (Hitachi F2000, Tokyo).

\section{(1) MCC and PP}

(1) Particle isolation

To isolate particles in mucus, water was added to mucus (collected in a $15 \mathrm{~mL}$ plastic centrifuge tube), the mixture made up to a total volume of $10 \mathrm{~mL}$, and the tube centrifuged $(3,000 \mathrm{rpm}$. for 10 minutes at $\left.15^{\circ} \mathrm{C}\right)$. After supernatant was decanted, $2 \mathrm{~mL}$ of $0.2 \mathrm{~N} \mathrm{NaOH}$ was added to the residue, and the mixture was heated at $50^{\circ} \mathrm{C}$ for 1 hour. Then, the tube was centrifuged, and the supernatant was decanted. The residue was washed with water by repeating $10 \mathrm{~mL}$ of water addition and centrifugation twice. Finally, the residue was washed with ethanol by repeating $10 \mathrm{~mL}$ of ethanol addition and centrifugation twice. The resultant residue was dried, and $2 \mathrm{~mL}$ of isopropyl alcohol was added to provide a dispersion for particle count determination by the image analyzer.

For the particle isolation in the nasal wash $(300 \mathrm{~mL})$, the wash was centrifuged $\left(3,000 \mathrm{rpm}\right.$ for 10 minutes at $\left.15^{\circ} \mathrm{C}\right)$, and the residue after decanting was transferred to a $15 \mathrm{~mL}$ plastic centrifuge tube. Then, the sample preparation method for particles in mucus was followed to give $2 \mathrm{~mL}$ of isopropyl alcohol dispersion for the determination.

For the collection of particles remaining in the capsule or device, the particles were washed by ethanol and separated by centrifugation $(3,000 \mathrm{rpm}$ for 10 minutes at $25^{\circ} \mathrm{C}$ ). The residue was then dried and dispersed in $2 \mathrm{~mL}$ of isopropyl alcohol for the determination.

(2) Particle count determination by image analysis Accurately weighed MCC (1 3 mg) or PP (1 $10 \mathrm{mg}$ ) was added to $1 \mathrm{~mL}$ of the control mucus, followed by the aforementioned isolation procedure. From the resultant isopropyl alcohol dispersion, $50 \mu \mathrm{L}$ was homogeneously spread on a $76 \mathrm{~mm} \times 26$ mm slide glass (Matsunami Glass, Japan). After the particles had been dried, the slide was scanned by the image analyzer (Pharmavision 830) to provide standard curves for the weight-count relationships. Then, the particle counts in the dispersions isolated from mucus, nasal wash, and capsule or device were measured, and the corresponding weights were determined 
from the standard curves.

\section{(2) FITC-HPC}

(1) Standard curve

The amounts of FITC-HPC in the mucus, nasal cavity wash, and capsule or device were determined by the fluorescence spectrophotometer. One hundred milligrams of FITC-HPC was weighed accurately and dissolved in $100 \mathrm{~mL}$ of ethanol to form a standard solution. Increasing amounts of solution, $5,10,20,50$, and $100 \mu \mathrm{L}$, were added to $1 \mathrm{~mL}$ of $0.01 \mathrm{M}$ phosphate buffer ( $\mathrm{pH} 8.0$ ), followed by ethanol addition to produce $10 \mathrm{~mL}$ of standard solutions. Fluorescence intensity measurements of the solutions at $508 \mathrm{~nm}$ excitation and 525 $\mathrm{nm}$ emission gave a standard regression curve : $y$ (intensity) $=2.7482 x$ (concentration) $-0.071, R^{2}=0.9999$.

(2) FITC-HPC determination

For the determination of FITC-HPC in mucus, $1 \mathrm{~mL}$ of the phosphate buffer was added to $0.1 \mathrm{~mL}$ of mucus and ethanol added to give $10 \mathrm{~mL}$ of solution. After centrifugation $(3,000 \mathrm{rpm}$ for 10 minutes at $15^{\circ} \mathrm{C}$ ), the fluorescence intensity of the supernatant was measured.

For FITC-HPC in the nasal wash, $1 \mathrm{~mL}$ of buffer was added to $9 \mathrm{~mL}$ of the wash and centrifuged. The fluorescence intensity of the supernatant was measured.

For FITC-HPC in the capsule or device, the capsule and nozzle of the device were washed with $50 \mathrm{~mL}$ of ethanol. One milliliter of the buffer was added to $1 \mathrm{~mL}$ of the wash and then ethanol added to give 10 $\mathrm{mL}$ of solution. The fluorescence intensity of the solution was then measured.

\section{In vitro fluorescein release from powder formulations}

A Franz-type cell, consisting of a release chamber covered horizontally with a $2.54 \mathrm{~cm}^{2}$ (available surface area) nitrocellulose membrane (Millipore Corporation, Boston, MA) with a $0.45 \mu \mathrm{m}$ pore
Tab.1 Particle size of the various materials determined by image analysis

\begin{tabular}{c|cccc}
\hline & Fluorescein & MCC & HPC & Lactose \\
\hline Image analyzer & FPIA3000 & $\begin{array}{c}\text { Pharmavision } \\
630\end{array}$ & $\begin{array}{c}\text { Pharmavision } \\
630\end{array}$ & $\begin{array}{c}\text { Pharmavision } \\
630\end{array}$ \\
\hline $\begin{array}{c}\text { Median of circle } \\
\text { equivalent } \\
\text { diameter }(\mu \mathrm{m})\end{array}$ & 1.28 & 53.91 & 61.97 & 84.38 \\
\hline
\end{tabular}

(Mean value, $\mathrm{n}=3$ )

diameter was used to monitor in vitro release. Prior to the experiment, the chamber ( $11.5 \mathrm{~mL}$ ) was filled with a $7: 3$ mixture of phosphate buffer ( $\mathrm{pH}$ 6.0) and ethanol, and kept at $37^{\circ} \mathrm{C}$. Thirty minutes later, $300 \mu \mathrm{L}$ of the release medium was added to the membrane to keep the membrane surface wet.

Then, $5 \mathrm{mg}$ of a powder formulation was homogeneously applied to the membrane. Ten microliters of the release medium was sampled periodically and added to $1 \mathrm{~mL}$ of $0.01 \mathrm{M}$ phosphate buffer ( $\mathrm{pH} \mathrm{8.0)}$ ), and then ethanol added to give $10 \mathrm{~mL}$ of solution for fluorescence intensity measurement.

\section{Data analysis}

The analytical methods used were the same as those reported in a previous study ${ }^{4)}$.

\section{Results}

\section{Particle sizes of materials}

The particle sizes of HPC and lactose are shown in Tab. 1 together with those of fluorescein and MCC, which were measured in a previous report ${ }^{4}$.

\section{Formulations and mucus excretion}

Fig. 1 shows the mucus volumes after administration of fluorescein formulations and carriers together with those of non-administered rabbits as a control. The volumes were not significantly different during the time courses. Between the same timings, the volumes were not significantly different from those of the control.

\section{Characterization of FITC-HPC (HPC (H))}

Gel-permeation studies showed that HPC gave 


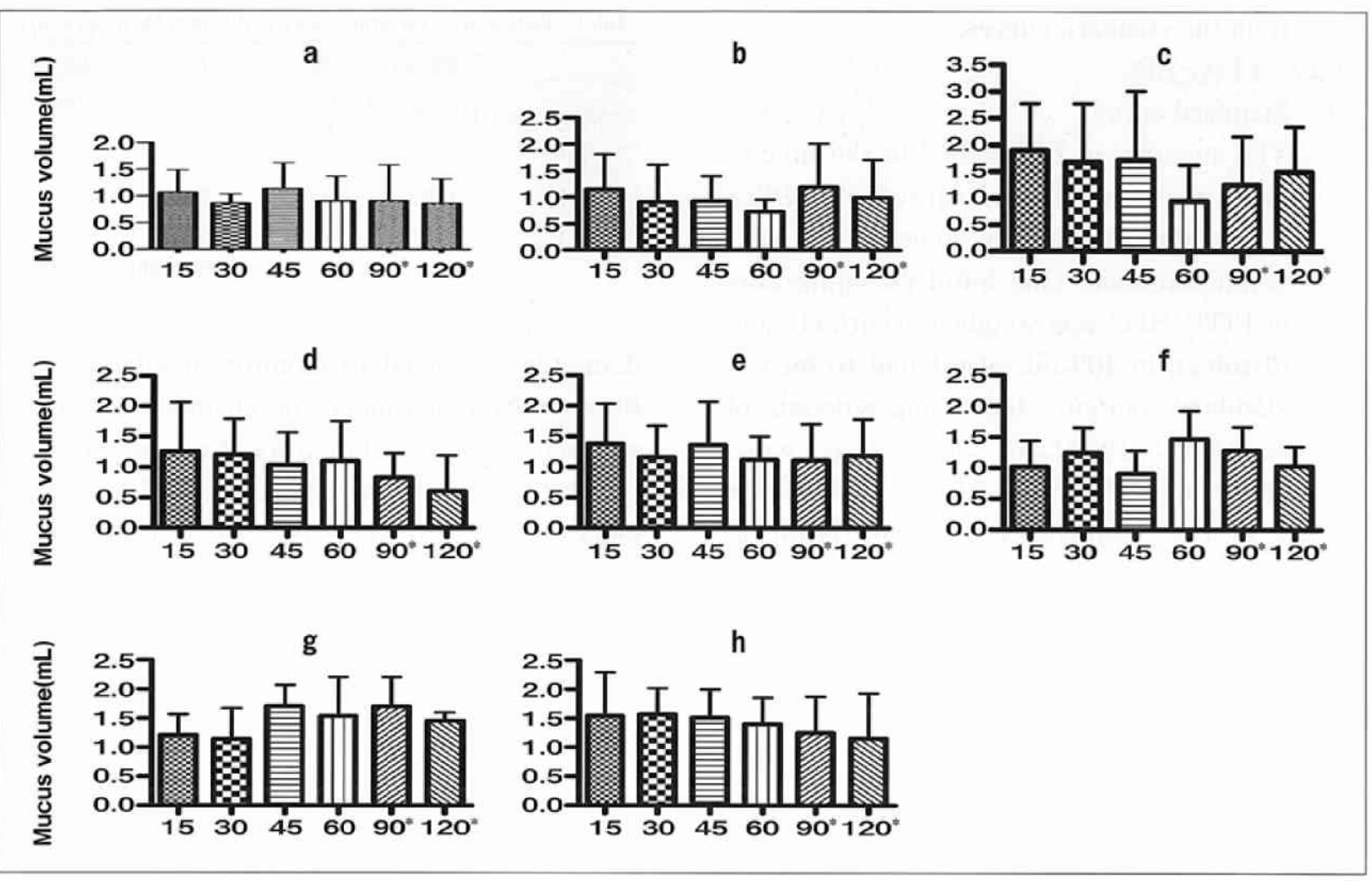

Fig.1 Mucus volumes as a function of time after recovery from anesthesia for the control group and after administration of fluorescein formulations or carriers

The bar indicates the SD ( $\mathrm{n}=6$ or 7$)$. Half of the excreted volume in 30 minutes is shown at 90 or $120 \mathrm{~min}$ (marked with an asterisk, "). (a) Control, (b) F/MCC, (c) F/lactose, (d) F/HPC,

(e) F/PP, (f) MCC, (g) FITC-HPC, (h) PP

no peak with the fluorescein detector, while the retention times for HPC with the RI detector and for FITC-HPC with the fluorescein detector or the RI detector were identical $(7.9 \mathrm{~min})$. In FITC-HPC chromatographs, no peak resulting from FITC was detected.

The viscosities of FITC-HPC (H) were compared to those of HPC-H at different concentrations in aqueous solution. The results at a shear rate 500/s, for example, are shown in Fig.2, and the results for FITC-HPC (M) and FITCHPC (L) are also shown for comparison. These references were prepared in the same way as for FITC-HPC (H). The curves for FITC-HPC-H and $\mathrm{HPC}-\mathrm{H}$ were almost identical.

The glucose unit determination showed that the degree of FITC substitution at HPC was calculated to be $0.0089 \mathrm{moL} / \mathrm{moL}$ glucose.

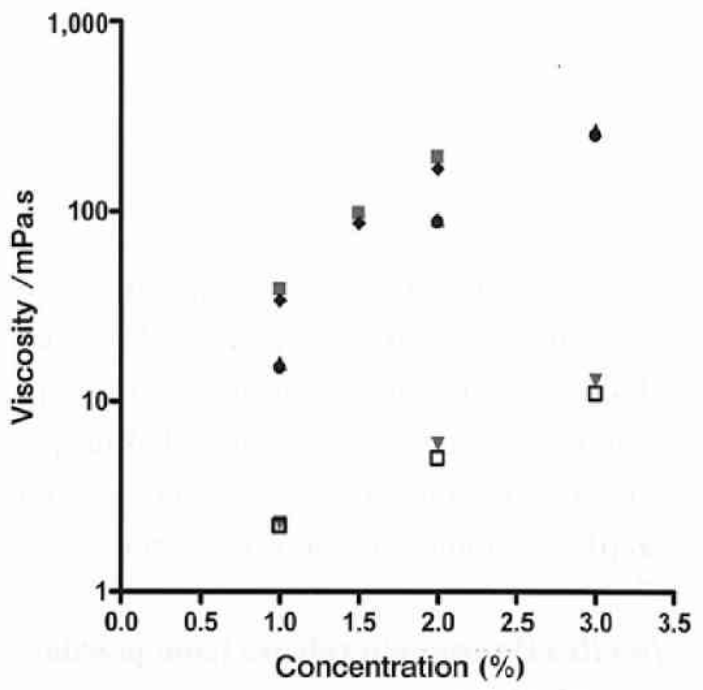

Fig.2 Viscosities of FITC-HPCs and HPCs in aqueous solution at $500 / \mathrm{m}$

a $\mathrm{FITC}-\mathrm{HPC}(\mathrm{H}), \Delta \mathrm{FITC}-\mathrm{HPC}(\mathrm{M})$

$\nabla$ FITC-HPC $(\mathrm{L}), \mathrm{HPC}(\mathrm{H})$

- $\operatorname{HPC}(\mathrm{M}), \mathrm{a} \mathrm{HPC}(\mathrm{L})$ 


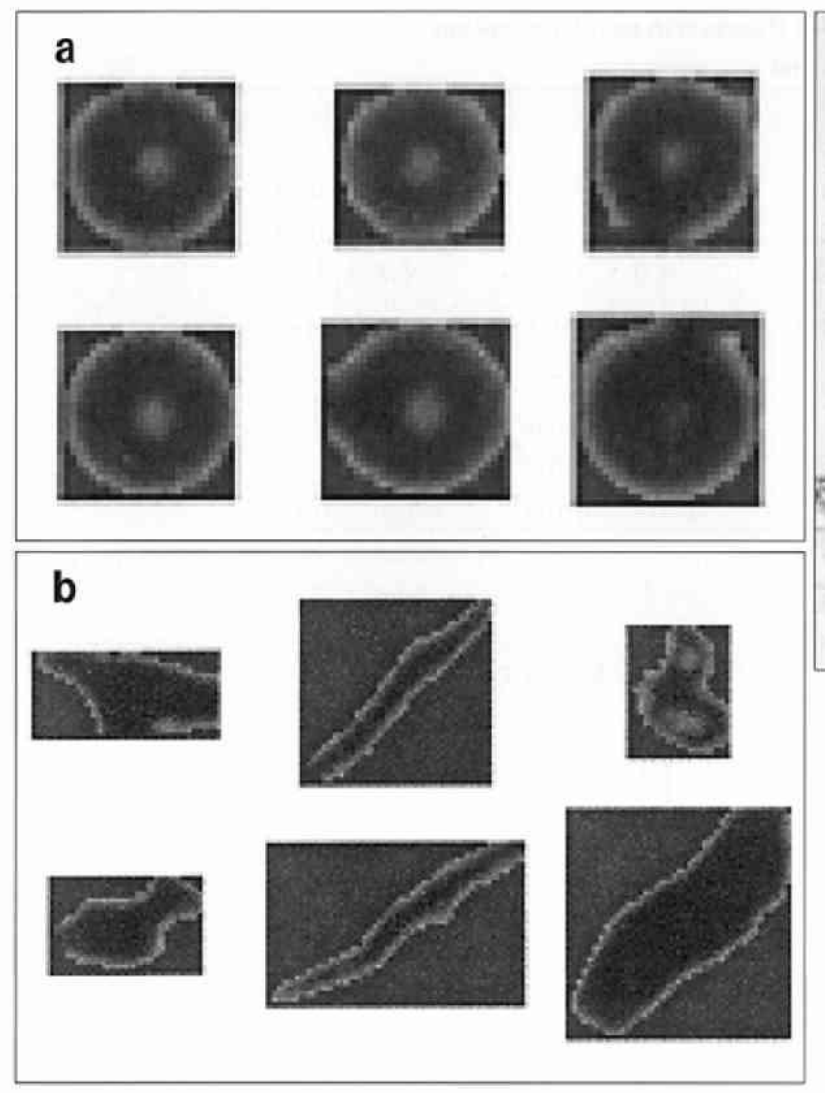

\section{Quantitative analysis of carriers}

Sample images of PP and MCC are shown in Fig.3ab, respectively. As PP is a standard particle and its diameter is closely controlled to around 80 $\mu \mathrm{m}$, concomitant images were cut off by adjusting the intensity, roundness, and size range. In MCCcount measurement, fractions smaller than $35 \mu \mathrm{m}$ were cut off to exclude tiny fragments formed during the sample preparation. Furthermore, mucous concomitants were cut off by adjusting the image intensity, as they appeared transparent and different to the MCC particles. An optical microscopy image of MCC and mucous concomitants is shown in Fig.3c.

The particle counts in $1 \mathrm{~mL}$ of mucus on the glass slide - particle weight in $1 \mathrm{~mL}$ of mucus relationships was plotted, and a linear regression lines was obtained. For MCC, $y$ (counts) = 1431.6x (weight) $-385.4, R^{2}=0.9989$. For PP, $y$ (counts) $=81.97 x$ (weight) $+12.71, R^{2}=$ 0.9938 . When nasal wash was used instead of mucus, the lines were identical.

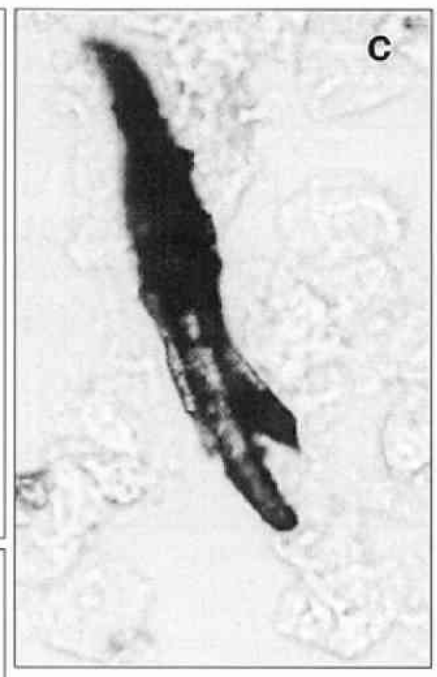

Fig.3

Image of insoluble particles

a : Example of an individual PP particle counted by the image analyzer (Pharmavision 830)

b : Example of an individual MCC particle counted by the same image analyzer

e : Optical microscopy image of MCC and concomitants from mucus

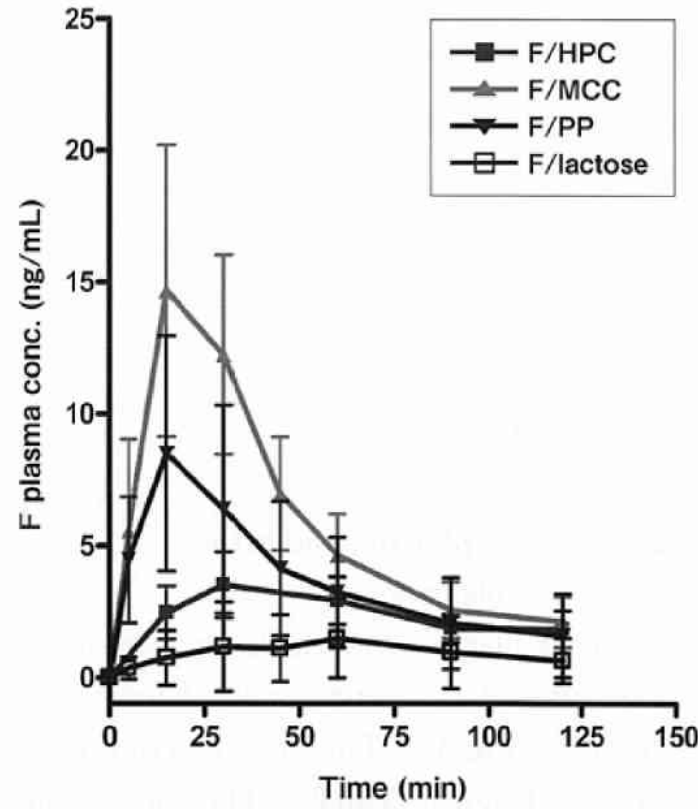

Fig.4 Mean plasma concentration-time profiles of fluorescein (F) after nasal administration with various carriers

The average F dose was $133.2 \mu \mathrm{g} /$ head for MCC $153.3 \mu \mathrm{g} / \mathrm{head}$ for HPC, $114.9 \mu \mathrm{g} /$ head for PP, and $108.7 \mu \mathrm{g} /$ head for lactose (mean $\pm \mathrm{SD}, \mathrm{n}=6$ ). 
Tab.2 Pharmacokinetic parameters of fluorescein nasal absorption for different powder formulations

\begin{tabular}{|c|c|c|c|c|}
\hline & $\mathrm{MCC}$ & HPC & $\mathrm{PP}$ & Lactose \\
\hline $\mathrm{n}$ & 6 & 6 & 6 & 6 \\
\hline Dose $(\mu \mathrm{g})$ & $133.2 \pm 8.1$ & $153.3 \pm 15.3$ & $114.9 \pm 9.5$ & $108.7 \pm 10.4$ \\
\hline$T_{\max }(\min )$ & $20.0 \pm 7.8$ & $32.5 \pm 14.8$ & $20.0 \pm 7.8$ & $36.0 \pm 13.4$ \\
\hline$C_{\max }(\mathrm{ng} / \mathrm{mL})$ & $15.6 \pm 5.2$ & $3.7 \pm 1.2$ & $9.0 \pm 4.1$ & $1.8 \pm 1.8$ \\
\hline $\begin{array}{l}\mathrm{AUC}_{0-120 \mathrm{~min}} \\
(\mathrm{ng} / \mathrm{mL} / \mathrm{min})\end{array}$ & $748.3 \pm 228.3$ & $287.2 \pm 83.8$ & $455.5 \pm 241.9$ & $117.6 \pm 116.8$ \\
\hline BA (\%) & $24.1 \pm 8.5$ & $7.9 \pm 2.1$ & $16.3 \pm 7.7$ & $4.7 \pm 4.8$ \\
\hline$K_{2}$ & $0.087 \pm 0.037$ & $\cdots$ & $0.104 \pm 0.048$ & $\cdots$ \\
\hline$K_{\mathrm{e}}$ & $0.034 \pm 0.006$ & $\cdots$ & $0.045 \pm 0.028$ & $\cdots$ \\
\hline$K_{\mathrm{ec}}$ & $0.066 \pm 0.022$ & $\cdots$ & $0.049 \pm 0.011$ & $0.090 \pm 0.029$ \\
\hline
\end{tabular}

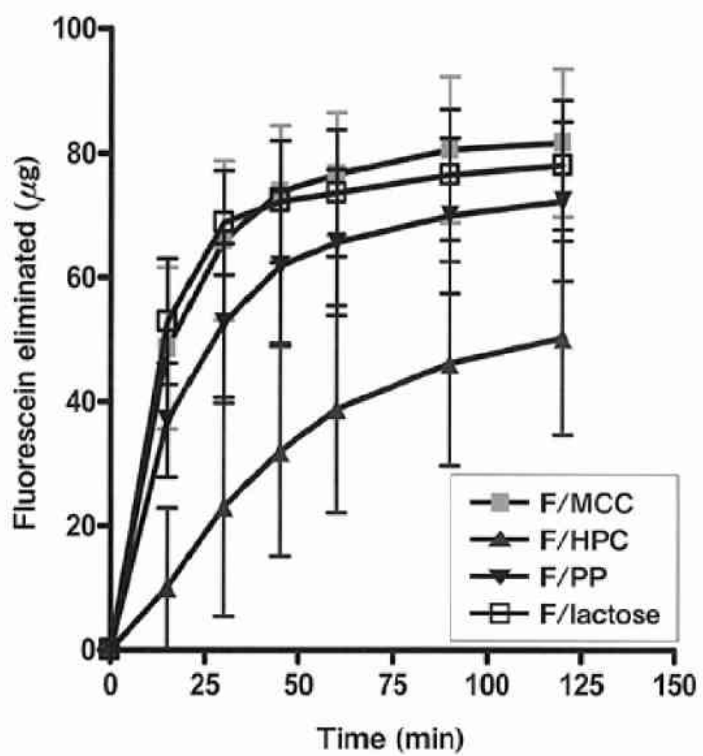

Fig.5 Cumulative amount of fluorescein eliminated into the esophagus after nasal administration with various carriers

The average $\mathrm{F}$ dose was $133.2 \mu \mathrm{g} /$ head for MCC, $153.3 \mu \mathrm{g} /$ head for HPC, $114.9 \mu \mathrm{g} /$ head for PP, and $108.7 \mu \mathrm{g} /$ head for lactose (mean $\pm \mathrm{SD}, \mathrm{n}=6$ ).

\section{Fluorescein pharmacokinetics}

\section{(1) Nasal absorption}

Fluorescein plasma concentration profiles after administration of the four kinds of formulations are shown in Fig.4. The pharmacokinetic parameters are listed in Tab.2. The formulation of MCC or PP showed a rapid and higher absorption, and the former showed superior effects. The HPC showed sustained and lower absorption, whereas lactose showed little absorption.

(2) Fluorescein elimination into the esophagus Fluorescein elimination profiles of the formula-

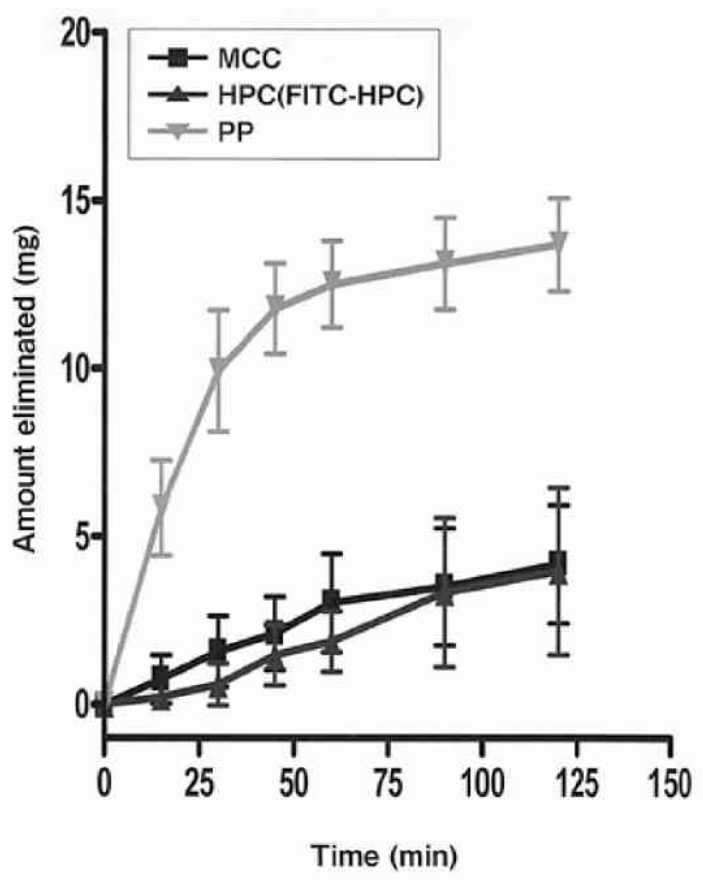

Fig.6 Cumulative amount of carriers eliminated into the esophagus after nasal administration (mean $\pm \mathrm{SD}, \mathrm{n}=6$ )

tions are shown in Fig.5. Eliminations with MCC, PP, or lactose were rapid ; the calculated first-order rate constants are listed in Tab.2. By contrast, HPC showed sustained fluorescein elimination.

\section{(3) Carrier elimination into the esophagus}

Carrier elimination profiles are shown in Fig.6. PP showed rapid elimination, and its first-order elimination rate constant was calculated to be $0.037 \pm 0.011 / \mathrm{min}$. The elimination of $\mathrm{MCC}$ and HPC was sustained. 


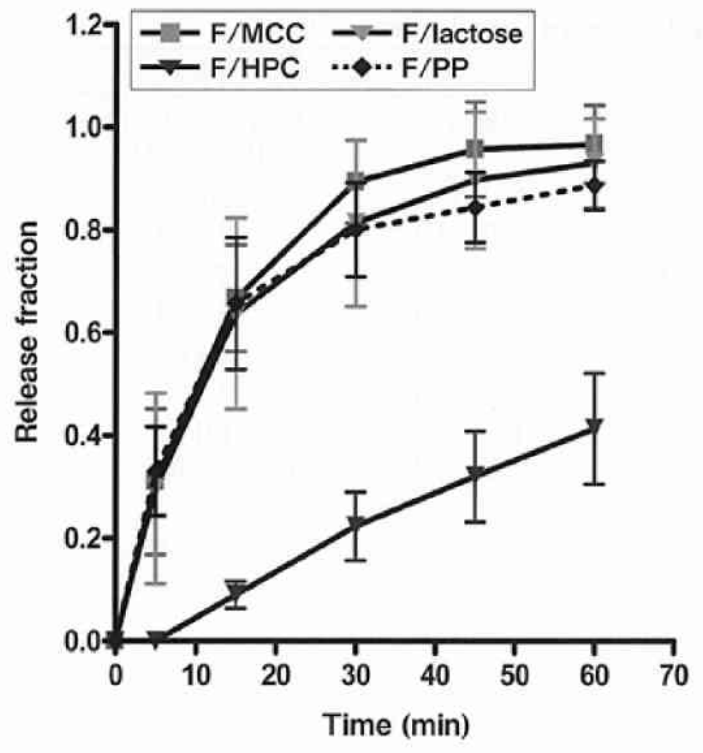

Fig.7 In vitro release of fluorescein from powder formulations (mean $\pm \mathrm{SD}, \mathrm{n}=3$ )

\section{(4) In vitro fluorescein release from the} formulations

In vitro fluorescein release profiles of the formulations are shown in Fig.7. The fluorescein release with $\mathrm{MCC}, \mathrm{PP}$, or lactose was rapid and similar under the experimental conditions. HPC, however, showed a delayed and sustained release. After the release experiments, fluorescein entrapped in the HPC gel was observed on the membrane.

\section{Discussion}

\section{Powder formulation}

In addition to the $\mathrm{F} / \mathrm{MCC}$ powder formulation in the previous report ${ }^{4}$, fluorescein in F/HPC, $\mathrm{F} / \mathrm{PP}$ or $\mathrm{F} /$ lactose formulations adhered to the carriers before and after administration by the spray device, which was confirmed by microscopic observations (data not shown). Therefore, the powder formulations did not contain any free fluorescein particles that may reach the lung and be absorbed by the pulmonary route. As the particle size of the carriers is large enough for the carriers to be deposited in the nasal cavity (Tab.1), fluorescein will be deposited there with the carriers, and its pharamacokinetics will be affected by the accompanying carriers.

\section{FITC-HPC}

Although HPC does not crystallize, it precipitates when its aqueous solution is heated. The solubilization-precipitation process was repeated, and purified FITC-HPC was obtained. The characterization studies showed that: (1) FITCHPC did not contain any unreacted FITC, (2) the viscosity properties of its aqueous solution are almost identical to those of HPC, and (3) FITC was introduced into the HPC chains so that it could be analyzed by fluorescence spectrophotometry. These results indicate that the FITC-HPC thus obtained could be used as a labeled compound of HPC for pharmacokinetic studies.

\section{Mucus excretion}

Mucociliary clearance can be affected by many factors, including drugs and the presence of drug formulations ${ }^{6)}$. In this animal model, anesthetics actually stopped mucus secretions temporally. The mucus volumes were measured and compared after administration of the powder formulations. The results showed that the volumes were not significantly different among the studied groups (Fig.1). Therefore, this indicated that the presence of the powder formulations did not affect the mucociliary clearance systems.

\section{Measurement of numbers of insoluble particles}

Mucus consists of approximately $95 \%$ water, $2 \%$ mucin, $1 \%$ salts, $1 \%$ other proteins and $<1 \%$ lipids $^{7)}$. Isolation of MCC or PP from mucus or nasal wash could not exclude those substances. However, PP could be easily separated by image analysis, as it contained a dye that gave a strong image intensity and was an almost perfect sphere, more round than other concomitants. MCC particles could also be easily separated from the concomitants, as they gave a stronger image intensity.

Fig.3c shows the difference in intensity from an optical microscopy image. The concentration of MCC dispersion was chosen so that the particles 
Tab.3 Mass balance of fluorescein after nasal administration with powder formulations ${ }^{2}$

\begin{tabular}{c|ccccc}
\hline & A & B & C & D & E \\
\hline Formulation & Administered $^{\mathrm{b}}$ & $\begin{array}{c}\text { Eliminated into } \\
\text { the esophagus }\end{array}$ & $\begin{array}{c}\text { Recovered from } \\
\text { the nasal cavity }\end{array}$ & Absorbed $^{\mathrm{c}}$ & $\begin{array}{c}\text { Mean mass balance } \\
\text { (B + C + D) }\end{array}$ \\
\hline F/MCC $(\mu \mathrm{g})$ & $133.2 \pm 8.1$ & $81.6 \pm 11.9$ & $4.6 \pm 2.0$ & $32.1 \pm 11.3$ & 118.3 \\
& & {$[0.613]$} & {$[0.035]$} & {$[0.241]$} & {$[0.888]$} \\
F/HPC $(\mu \mathrm{g})$ & $153.3 \pm 15.3$ & $50.2 \pm 15.6$ & $11.9 \pm 4.1$ & $12.1 \pm 3.3$ & 74.2 \\
& & {$[0.327]$} & {$[0.078]$} & {$[0.079]$} & {$[0.484]$} \\
F/lactose $(\mu \mathrm{g})$ & $108.7 \pm 10.4$ & $78.1 \pm 10.5$ & $7.4 \pm 6.3$ & $5.1 \pm 5.2$ & 90.6 \\
F/PP $(\mu \mathrm{g})$ & $114.9 \pm 9.5$ & $66.9 \pm 16.2$ & $15.7 \pm 8.4$ & $18.7 \pm 8.9$ & {$[0.833]$} \\
& & {$[0.582]$} & {$[0.137]$} & {$[0.163]$} & {$[0.87 .3$} \\
\hline
\end{tabular}

$\mathrm{n}=6 \quad($ mean $\pm \mathrm{SD})$

b Administered : [formulated in capsule] - [recovered from capsule and device]. F/MCC : [173.2 \pm 2.4$]-[40.0$

$\pm 6.8]$. F/HPC : [189.2 \pm 2.6$]-[35.9 \pm 14.2]$. F/lactose : [170.2 \pm 2.1$]-[61.5 \pm 9.7] . \mathrm{F} / \mathrm{PP}:[164.6 \pm 4.0]$

$-[49.7 \pm 8.2]$

'Calculated from BA data.

[] : recovery (each mean value/A mean value)

might not aggregate. MCC is insoluble, and no labeling method is currently available. This measurement of particle numbers by image analysis is an easy quantification method for such solid particles.

\section{Effects of carriers on fluorescein nasal pharmacokinetics}

The AUCs for $\mathrm{F} / \mathrm{MCC}$ and $\mathrm{F} / \mathrm{PP}$ were significantly greater than that of $\mathrm{F} /$ lactose (Fig.4, Tab.2). As the AUC for the fluorescein aqueous suspension was almost the same as that for F/lactose ${ }^{4)}$, insoluble MCC and PP highly enhanced fluorescein nasal absorption. MCC is known to enhance nasal absorption of soluble salmon calcitonin ${ }^{2)}$. The present results show that it enhanced absorption of hydrophobic fluorescein as well as that of hydrophilic calcitonin. Although the mechanism responsible for the enhancement is not currently known, it is presumably not related to a tight junction opening, which favors hydrophilic compounds. MCC showed a superior enhancement effect to PP, although it was not significantly different. Fluorescein elimination into the esophagus for the two formulations was rapid and not significantly different (Fig.5, Tab.2). In vitro fluorescein release from the formulations was also rapid and similar (Fig.7). However, elimination of the carriers themselves into the esophagus contrasted sharply between the two formulations (Fig.6). The cavity eliminated PP rapidly, while MCC was retained in the cavity and excreted slowly. PP has a smooth and hydrophobic surface, which probably has little interaction with components of mucus or the mucosal membrane, followed by rapid clearance with mucus flow. On the contrary, MCC is water-absorbing and hydrophilic, and presumably has bioadhesive interactions with the components of the cavity, followed by a long residence time. Local high and prolonged concentrations of fluorescein likely contribute to the enhanced absorption. A similar enhanced drug absorption and prolonged residence time have been reported for starch and chitosan microspheres ${ }^{8)}$.

The F/HPC formulation showed a lower and sustained fluorescein absorption (Fig.4). Elimination of both fluorescein and HPC itself was sustained (Fig.5, 6). In vitro fluorescein release from the formulations was also sustained (Fig.7). These results indicate that HPC absorbs water on the nasal membrane and forms gel in the mucus, thus resulting in a longer residence time on the membrane. Although the gel may have been near the mucosal membrane, fluorescein release through the HPC gel was slow, and its absorption was lower than that for MCC or PP.

Though lactose showed a rapid fluorescein re- 
lease in the in vitro study (Fig.7), fluorescein was not absorbed (Fig.4) but rapidly eliminated into the esophagus (Fig.5). Lactose is water-soluble and probably dissolves in the mucus rapidly once F/lactose particles have been deposited. Compared to insoluble carriers, there is presumably no space for a local high concentration of fluorescein to form. The poor absorption by the aqueous suspension probably supports this mechanism.

Tab. 3 shows the mass balance of fluorescein administered intranasally. Except for F/HPC, the recovery was good and indicates that this experimental model is suitable for quantitative studies. In the case of $\mathrm{F} / \mathrm{HPC}$, fluorescein is probably entrapped in the HPC gel, and it may reduce fluorescein recovery from the nasal cavity. The low recovery of FITC-HPC from the cavity may support the low value.

In conclusion, the newly developed methods made pharmacokinetic studies of drug and carriers in the nasal cavity possible, which could clarify the different pharmacokinetic profiles between the formulations.

\section{References}

1) Nagai T, Nishimoto Y, Nambu N, Suzuki Y, Sekine K : Powder dosage form of insulin for nasal administration. J Control Rel $1: 15-22,1984$.

2) Suzuki Y, Makino Y : Mucosal drug delivery using cellulose derivatives as a functional polymer. J Control Rel 62 : 101-107. 1999.

3) Ishikawa F, Murano M, Hiraishi M, Yamahuchi T, Tamai I et aL. : Insoluble powder formulation as an effective nasal drug delivery system. Pharm Res 19: 1097-1104, 2002.

4) Makino Y, Nishibe Y, Matsugi H, Nishimura Y, Katsyuyama I : A new in vivo animal model for nasal pharmacokinetic studies. Drug Deliv Syst 20:543-550. 2005.

5) Sakon K, Sakagami M, Makino Y, Fujii T : Fluorescencelabeled cellulose derivatives. Japan Patent Application : No. 100001, 1996.

6) Song Y, Wang Y, Thaker R, Meidan VM, Michniak G : Mucosal drug delivery ; mebranes, methodologies, and applications. Crit Rev Ther Drug Carrier Syst 21 : 195-256. 2004.

7) Kaliner M, Marom Z, Patow C, Shelhamer J. : Human respiratory mucus. J Allergy Clin Immunol $73: 318-323$. 1984.

8) Soane RJ, Frier M, Perkins AC, Jones NS, Davis SS et al. : Evaluation of the clearance characteristics of bioadhesive systems in humans. Int J Pharmaceut $178: 55-65,1999$. 